\title{
A case report: white cord syndrome following anterior cervical discectomy and fusion: importance of prompt diagnosis and treatment
}

\author{
Deuk Soo Jun, Jong-Min Baik ${ }^{*}$ and Seung-Kwan Lee
}

\begin{abstract}
Background: Objective: White cord syndrome is extremely rare and search of the literature has revealed very few cases. Postoperative MR scan revealed hyperintense intrinsic cord signal changes within cord ischemia and edema. It is thought to be caused by reperfusion injury of the spinal cord. This is called white cord syndrome. This report is very rare case of 'White Cord Syndrome' with paraplegia after anterior cervical discectomy and fusion (ACDF).

Case presentation: A 49-year-old woman presented with neck pain lasting for several months and second and third finger radiating pain. Severe cervical herniated intervertebral disc findings could be identified at C6-7 level on C-spine MRI. ACDF C6-7 surgery was performed. Immediately after the operation, physical examination revealed paraplegia and emergency MRI was performed. On MR images, T2 high signal myelopathy suspected as reperfusion injury at C6-7 level, and emergency surgery was performed under diagnosis of white cord syndrome. After the emergency operation, the paraplegic problem was gradually resolved. Before discharge, motor power and sensory deficit of bilateral lower extremity were fully recovered.

Conclusion: Surgeons should explain the possibility of white cord syndrome before cervical decompression surgery and should perform a neurological examination immediately after surgery. We recommend that the importance of early recognition and prompt treatment of white cord syndrome.
\end{abstract}

Keywords: Cervical, Huge disc, discectomy, Fusion, White cord syndrome

\section{Background}

Anterior cervical discectomy and fusion (ACDF) is a common surgical procedure for cervical spine surgery and has resulted in good clinical results. The most serious complication after cervical spine surgery is neurologic deficit such as paralysis or paraplegia. This paraplegia is reported to be mostly caused by hematoma or iatrogenic injury. However, there is paraplegia that

\footnotetext{
* Correspondence: bbaik@hanmail.net

Department of Orthopedic Surgery, Gil Medical Center, Gachon University College of Medicine, University of Gachon, 21, Namdong-daero 774, Namdong-gu, Incheon, Republic of Korea
}

cannot be explained by these things, which can be caused by reperfusion injury, so called 'white cord syndrome' [1]. White cord syndrome is extremely rare and search of the literature has revealed very few cases. Postoperative MR scan revealed hyperintense intrinsic cord signal changes within cord ischemia and edema. It is thought to be caused by reperfusion injury of the spinal cord. Although the mechanism of the disease is not clear, it is believed that free radical oxygen damages the spinal cord [2-4]. We report a case of this complication after ACDF.

C C The Author(s). 2020 Open Access This article is licensed under a Creative Commons Attribution 4.0 International License, which permits use, sharing, adaptation, distribution and reproduction in any medium or format, as long as you give appropriate credit to the original author(s) and the source, provide a link to the Creative Commons licence, and indicate if changes were made. The images or other third party material in this article are included in the article's Creative Commons licence, unless indicated otherwise in a credit line to the material. If material is not included in the article's Creative Commons licence and your intended use is not permitted by statutory regulation or exceeds the permitted use, you will need to obtain permission directly from the copyright holder. To view a copy of this licence, visit http://creativecommons.org/licenses/by/4.0/. The Creative Commons Public Domain Dedication waiver (http://creativecommons.org/publicdomain/zero/1.0/) applies to the data made available in this article, unless otherwise stated in a credit line to the data. 

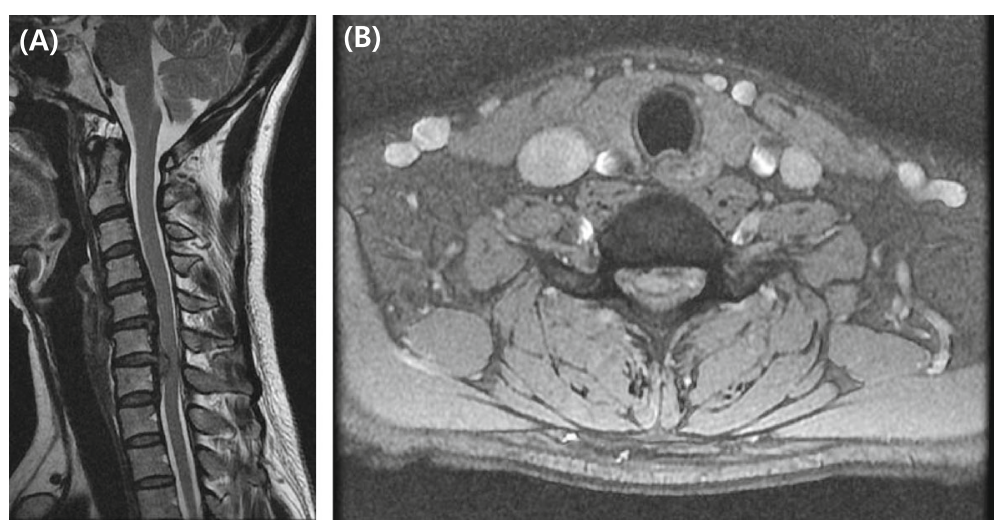

Fig. 1 a Preoperative sagittal T2 weighted MR images showing large central disc extrusion with inferior migration, severe cord compression on C6-7 level. b Preoperative axial T2-weighted MRI showing severe C6-7 cord compression by a massive disc herniation

\section{Case presentation}

This 49-year-old woman presented with neck pain lasting for several months and second and third finger radiating pain. She had no neurological deficit except for severe radiating pain of C6 dermatome. And the myelopathic neurologic examinations were uneventful, such as Hoffman's sign, knee jerk, and ankle clonus. There was no past history other than hypertension and no relevant past medical interventions. On the Cspine MRI, we were able to confirm that the cord was compressed by extrusion of the large central disc at the C6-7 level (Fig. 1a, b). ACDF C6-7 surgery was performed and the cord was decompressed by removing the $\mathrm{C} 6-7$ disc material. The interbody cage was inserted into the $\mathrm{C} 6-7$ disc space and the plate (Vectra $^{\mathrm{mu}}$, Depuy Synthes, CH) was fixed on the C6-7 body anterior surface. On immediately postoperative physical examination, the upper extremity motor and sensory nerves were normal however, ankle clonus
$4+$, knee jerk 4+, sensory deterioration, and bilateral lower extremity motor grade 0 were confirmed. Cspine MRI was taken immediately. Wide spreading high signal intensity in sagittal STIR (Short tau inversion recovery) MR image was observed at C6-7 level (Fig. 2a). In axial T2-weghted MR, anterior bilateral symmetric ovoid foci of high signal intensity (the snake-eyes sign) was observed (Fig. 2b). She was started high dose steroid (Methylprednisolone $30 \mathrm{mg} /$ $\mathrm{kg} / 15 \mathrm{~min}+5.4 \mathrm{mg} / \mathrm{kg} / 23 \mathrm{~h}$ ) was administered under white cord syndrome diagnosis and emergency operation was performed. She underwent laminoplasty (Centerpiece ${ }^{\mathrm{pt}}$, Medtronic, USA) operation at C4-5-67 levels. The T2 weighted MR scan was repeated 1 week later as seen in Fig. 3a, b. After surgery, motor and sensory deficits were gradually resolved. Before discharge, motor power and sensory deficit of bilateral lower extremity were fully recovered. However, mild tingling sensation was remained at bilateral L5, S1
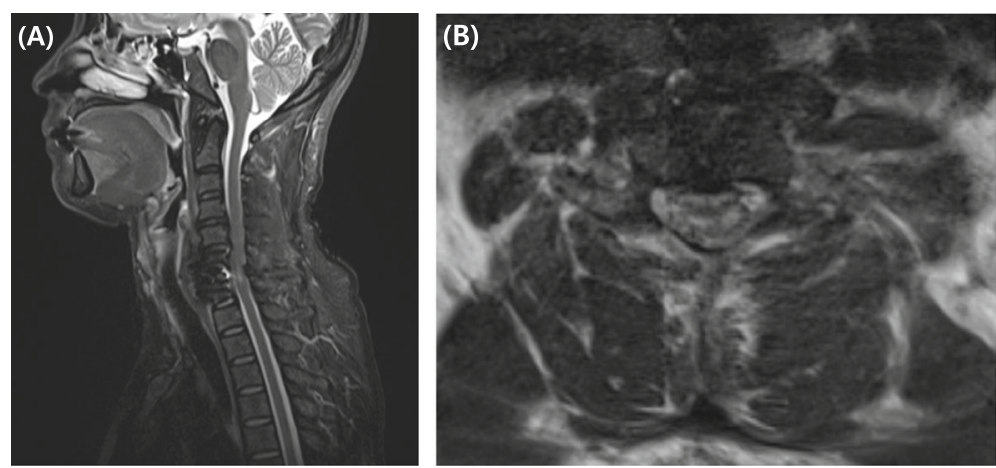

Fig. 2 a Immediate postoperative sagittal STIR (Short tau inversion recovery) MR image shows cervical anterior decompression state and high signal intensity at C6-7 level. b Immediate postoperative axial T2 weighted MR image shows anterior bilateral symmetric ovoid foci of high signal intensity at C6-7 level 

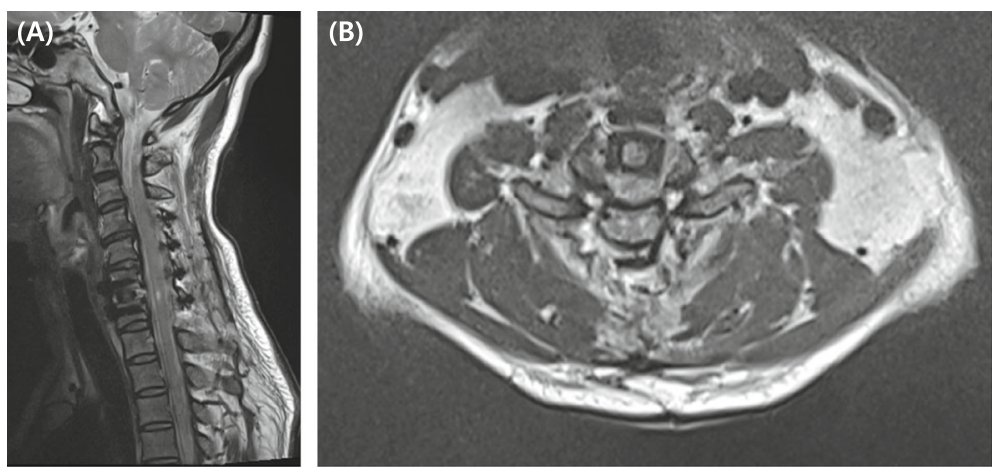

Fig. 3 a One week postoperative sagittal T2 weighted MR image showing high intensity patchy signal changes within the cord with cord swelling as called White cord syndrome. b One week postoperative axial T2 weighted MR Image showing 2 points high signal intensity at C6-7 level

dermatome area. The patient had been discharged at 14 days postoperatively, and the preoperative symptoms almost disappeared (Table 1).

\section{Discussion and conclusions}

White cord syndrome is extremely rare and search of the literature has revealed very few cases. Chin at al [5]. reported the case of a 59-year-old man affected by $\mathrm{C} 5-6$ severe cord compression, who underwent C4-5 and C5-6 ACDF surgery. Tetraplagia occurred in the patient after surgery, and he was treated with more extensive decompression and steroids immediately. The patient was partially improved. And Giammalva et al. [6] reported the case of a 64-year-old man affected by C4-6 severe cord compression, who underwent C3-4 and C5-6 ACDF. Tetraparesis occurred in the patient after surgery, and the patient was immediately started only high-dose steroid protocol (NASCIS III). The patient was partially improved. Antwi et al. [7] reported the case of a 68-year-old man affected by C4-6 severe cervical stenosis, who underwent $\mathrm{C} 3-7$ posterior decompression surgery.

Table 1 Neurological assessment: American Spinal Injury (ASIA) scale

\begin{tabular}{|c|c|c|c|c|}
\hline & & Motor Gr (Rt/Lt) & Sensory Gr (Rt/Lt) & ASIA impairment scale \\
\hline \multirow[t]{5}{*}{ Before first operation } & L2, Hip flexors & $5 / 5$ & $2 / 2$ & \multirow[t]{5}{*}{$E$} \\
\hline & L3, Knee extensors & $5 / 5$ & $2 / 2$ & \\
\hline & L4, Ankle dorsiflexors & $5 / 5$ & $2 / 2$ & \\
\hline & L5, Long toe extensiors & $5 / 5$ & $2 / 2$ & \\
\hline & S1, Ankle Plantar flexors & $5 / 5$ & $2 / 2$ & \\
\hline \multirow[t]{5}{*}{ After first operation } & L2, Hip flexors & $0 / 0$ & $0 / 0$ & \multirow[t]{5}{*}{ A } \\
\hline & L3, Knee extensors & $0 / 0$ & $0 / 0$ & \\
\hline & L4, Ankle dorsiflexors & $0 / 0$ & $0 / 0$ & \\
\hline & L5, Long toe extensiors & $0 / 0$ & $0 / 0$ & \\
\hline & S1, Ankle Plantar flexors & 0/0 & $0 / 0$ & \\
\hline \multirow[t]{5}{*}{ After second operation ( 1 day) } & L2, Hip flexors & $4 / 4$ & $1 / 1$ & \multirow[t]{5}{*}{$\mathrm{D}$} \\
\hline & L3, Knee extensors & $4 / 4$ & $1 / 1$ & \\
\hline & L4, Ankle dorsiflexors & $4 / 4$ & $1 / 1$ & \\
\hline & L5, Long toe extensiors & $4 / 4$ & $1 / 1$ & \\
\hline & S1, Ankle Plantar flexors & $4 / 4$ & $1 / 1$ & \\
\hline \multirow[t]{5}{*}{ After second operation (14 days) } & L2, Hip flexors & $5 / 5$ & $2 / 2$ & \multirow[t]{5}{*}{$E$} \\
\hline & L3, Knee extensors & $5 / 5$ & $2 / 2$ & \\
\hline & L4, Ankle dorsiflexors & $5 / 5$ & $2 / 2$ & \\
\hline & L5, Long toe extensiors & $5 / 5$ & $2 / 2$ & \\
\hline & S1, Ankle Plantar flexors & $5 / 5$ & $2 / 2$ & \\
\hline
\end{tabular}


Table 2 Demographics and Clinical Characteristics of other cases

\begin{tabular}{|c|c|c|c|c|c|c|}
\hline Case & Age/Sex & Diagnosis & Treatment & $\begin{array}{l}\text { Symptom after first } \\
\text { operation }\end{array}$ & $\begin{array}{l}\text { Treatment after first } \\
\text { operation }\end{array}$ & Final outcome \\
\hline Chin et al. & 59 / Male & CSM & $\begin{array}{l}\text { ACDF C4-5, } \\
\text { C5-6 }\end{array}$ & Incomplete tetraplegia & $\begin{array}{l}\text { 1. High-dose steroid } \\
\text { protocol } \\
\text { 2. C5 corpectomy }\end{array}$ & $\begin{array}{l}\text { Left finger flexion } 3 / 5 \\
\text { Left finger extension and } \\
\text { interossei } 4 / 5 \\
\text { Left hip abduction } 5-/ 5 \\
\text { Left quadriceps and hamstring } 4 / 5 \\
\text { Left other muscle groups } 2 / 5 \\
\text { Right lower limb } 5 / 5\end{array}$ \\
\hline $\begin{array}{l}\text { Giammalva } \\
\text { et al. }\end{array}$ & 64 / Male & CSM & $\begin{array}{l}\text { ACDF C3-4, } \\
\text { C5-6 }\end{array}$ & Tetraparesis & $\begin{array}{l}\text { 1. High dose steroid } \\
\text { protocol }\end{array}$ & $\begin{array}{l}\text { Right hand prehension } 3 / 5 \\
\text { Right arm flexion } 2 / 5 \\
\text { Both leg flexion } 2 / 5\end{array}$ \\
\hline Antwi et al. & 68 / Male & CSM & PCDF C3-7 & Hemiparesis (Left) & $\begin{array}{l}\text { 1. High-dose steroid } \\
\text { protocol }\end{array}$ & $\begin{array}{l}\text { Left wrist flexion } 3 / 5 \\
\text { Left wrist extension } 4+/ 5 \\
\text { Left elbow flexion } 4+/ 5 \\
\text { Left elbow extension } 4+/ 5 \\
\text { Left hip flexion } 2+/ 5 \\
\text { Left knee extesion } 4 / 5 \\
\text { Left ankle dorsiflexion 1/5 } \\
\text { Left ankle plantar flexion } 2 / 5\end{array}$ \\
\hline Our case & $\begin{array}{l}49 / \\
\text { Female }\end{array}$ & CSR & ACDF C6-7 & Paraplegia & $\begin{array}{l}\text { 1. High-dose steroid } \\
\text { protocol } \\
\text { 2. Laminoplasty C4-5-6-7 }\end{array}$ & Both lower limb full strength \\
\hline
\end{tabular}

${ }^{a}$ CSM Cervical spondylotic myelopathy, CSR Cervical spondylotic radiculopathy, $A C D F$ Anterior cervical discectomy and fusion, $P C D F$ Posterior cervical decompression and fusion

This was the first white cord syndrome case caused by posterior cervical operation. Hemiparesis occurred in the patient after surgery, and the patient was immediately started high-dose steroid protocol. But, the patient was partially improved. The precise mechanism of development of the white cord syndrome has not been reported. However, it is presumed that reperfusion injury occurs in chronically ischemic tissue caused by free radical oxygen. Hall E [8]. reports that the use of high-dose steroids inhibits the attack of free radical oxygen.

In our case, the patient had chronic severe cord compression, and the result of cord decompression was an unexpected neurological deficits. Postoperative T2weighted MRI showed intramedullary hyperintensity and cord swelling. So we used high-dose steroids to reduce oxidative damage and performed extensive decompression to relieve localized cord expansion. However, there is insufficient evidence to suggest that this has helped the patient improve symptoms. So we performed immediately surgery as laminoplasty at C4-5-6-7. The reason for choosing laminoplasty was to perform a quick operation and to decompress more widely while saving the neck motion (Table 2). We were convinced that there was no injury during surgical procedure, and we could conclude that neurological deficit occurred as an unknown cause, that is, reperfusion mechanisms. This is mentioned in some literature and is due to oxidative stress, although the exact cause is not known.

In conclusion, High-dose steroids and extensive decompression surgery in post-operative white cord syndrome is controversial but we think it is one of the available treatments. And also surgeons should adequately explain and give warning the possibility of complication, such as white cord syndrome before surgery and check the neurological examination immediately after surgery in patient with severe cord compression. We recommend that the importance of early recognition and prompt treatment of white cord syndrome.

Abbreviation

ACDF: Anterior cervical discectomy and fusion

\section{Acknowledgements}

Not applicable.

\section{Authors' contributions}

Conception and design: DSJ, JMB, SKL. Acquisition of data: DSJ, JMB, SKL. Analysis and interpretation of data: SKL, JMB. Drafting the article: JMB. Study Supervision: JMB. The authors read and approved the final manuscript.

\section{Funding}

This research did not receive any specific grant from funding agencies in the public, commercial, or not-for-profit sectors.

\section{Availability of data and materials}

The datasets used and/or analyzed during the present study are available from the corresponding author on reasonable request.

\section{Ethics approval and consent to participate}

This study was approved by the institutional review board of Gachon University Gil Medical Center (ethics approval code: GAIRB No. 2019-354). The need for consent was waived by the institutional review board of Gachon University Gil Medical Center (ethics approval code: GAIRB No. 2019354). Radiologic images are entirely unidentifiable and there are no details on individuals reported within the manuscript. 


\section{Consent for publication}

We obtained our institutional review board (GAIRB No.: 2017-354). And written informed consent was obtained from the patient for publication of this case report and any accompanying images. A copy of the written consent is available for review by the Editor of this journal.

\section{Competing interests}

The authors declare that they have no competing interests.

Received: 7 May 2019 Accepted: 24 February 2020

Published online: 12 March 2020

\section{References}

1. Vinodh VP, Rajapathy SK, Sellamuthu P, Kandasamy R. White cord syndrome: a devastating complication of spinal decompression surgery. Surg Neurol Int. 2018;9:136.

2. Chan PH. Role of oxidants in ischemic brain damage. Stroke. 1996;27:11249.

3. Shan LQ, Ma S, Qiu XC, Zhou Y, Wheng LH, Ren PC, et al. Hydroxysafflor yellow a protects spinal cords from ischemia/reperfusion injury in rabbits. BMC Neurosci. 2010;11:98.

4. Chan PH. Mitochondria and neural death/survival signaling pathways in cerebral ischemia. Neurochem Res. 2004;29:1943-9.

5. Chin KR, Seale J, Cumming V. "White cord syndrome" of acute tetraplegia after anterior cervical decompression and fusion for chronic spinal cord compression: a case report. Case Rep Orthop. 2013;2013:697918.

6. Giammalva GR, Maugeri R, Graziano F, Guli C, Giugno A, Basile L, et al. White cord syndrome after non-contiguous double-level anterior cervical decompression and fusion (ACDF): a "no reflow phenomenon"? Interdiscip Neurosurg. 2017;7:47-9.

7. Antwi P, Grant R, Kuzmik G, Abbed K. "White cord syndrome" of acute hemiparesis after posterior cervical decompression and fusion for chronic cervical stenosis. World Neurosurg. 2018;113:33-6.

8. Hall ED. Neuroprotective actions of glucocorticoid and nonglucocorticoid steroids in acute neuronal injury. Cell Mol Neurobiol. 1993;13:415-32.

\section{Publisher's Note}

Springer Nature remains neutral with regard to jurisdictional claims in published maps and institutional affiliations.

Ready to submit your research? Choose BMC and benefit from:

- fast, convenient online submission

- thorough peer review by experienced researchers in your field

- rapid publication on acceptance

- support for research data, including large and complex data types

- gold Open Access which fosters wider collaboration and increased citations

- maximum visibility for your research: over $100 \mathrm{M}$ website views per year

At $\mathrm{BMC}$, research is always in progress.

Learn more biomedcentral.com/submissions 